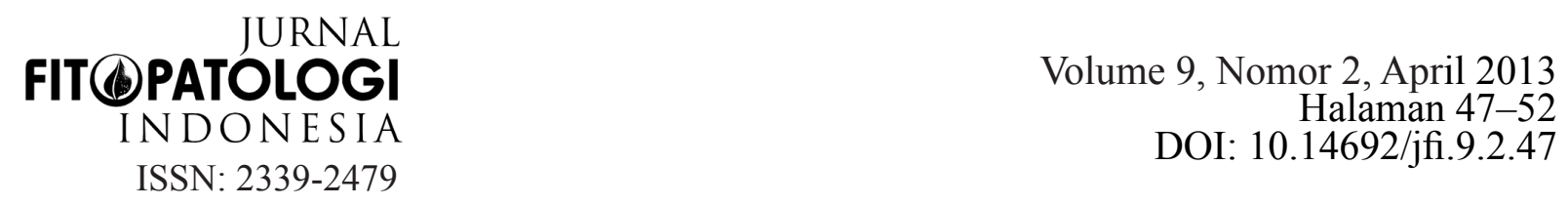

\title{
Deteksi dan Identifikasi Virus pada Umbi Bawang Merah
}

\author{
Detection and Identification of Plant Viruses on Shallot
}

\author{
Arif Kurniawan ${ }^{1,2}$, Gede Suastika ${ }^{1 *}$ \\ ${ }^{1}$ Institut Pertanian Bogor, Bogor 16680 \\ ${ }^{2}$ Badan Karantina Pertanian, Jakarta 12550
}

\begin{abstract}
ABSTRAK
Bawang merah merupakan komoditas hortikultura penting di Indonesia. Salah satu pembatas produksinya ialah penyakit yang disebabkan virus. Penyebaran virus pada bawang merah dapat melalui umbi yang diperdagangkan, namun belum banyak informasi terkait virus-virus terbawa umbi bawang. Penelitian ini bertujuan mendeteksi dan mengidentifikasi virus yang berasosiasi dengan umbi bawang merah. Pengambilan sampel dilakukan secara acak terhadap beberapa varietas bawang merah (varietas Jawa, Biru, Nganjuk dan Brebes) yang diperoleh dari Kabupaten Bantul, Yogyakarta. Deteksi dan identifikasi virus menggunakan metode RT-PCR dengan primer spesifik OYDV, SYSV, SLV, dan ShVX, serta perunutan nukleotida. RT-PCR hanya berhasil mengamplikasi Shallot yellow stripe virus (SYSV) dengan ukuran pita DNA $749 \mathrm{pb}$ dan virus lainnya tidak terdeteksi. Kejadian SYSV pada umbi bawang merah varietas Jawa dan Brebes berturut-turut 60\% dan 53.3\%. Perunutan DNA menunjukkan homologi nukleotida tertinggi terhadap SYSV asal Cina dan Korea Selatan.
\end{abstract}

Kata kunci: perunutan nukleotida, RT-PCR, Shallot yellow stripe virus

\begin{abstract}
Shallot is an important horticultural crop in Indonesia. One of it's production constraint is viral disease. Dispersal of viruses on shallots may occurre through shallots bulb trading. However, there is not much information regarding viruses infecting shallot bulbs. Laboratory study was conducted to detect and identify viruses associated with shallot. Random sampling was done for several varieties of shallots (Jawa, Biru, Nganjuk, and Brebes varieties) collected from Bantul Districs. Virus detection and identification was based on RT-PCR using specific primer of OYDV, SYSV, SLV, and ShVX followed by sequencing of the nucleotides. RT-PCR was only successfully amplified Shallot yellow stripe virus (SYSV) with size 749 bp, while other viruses were not detected. Disease incidence of SYSV on Java and Brebes varieties were $60 \%$ and $53.3 \%$ respectively. Nucleotide sequences of SYSV CP gene showed the highest homology to SYSV from China and South Korea.
\end{abstract}

Key words: RT-PCR, sequencing nucleotides, Shallot yellow stripe virus

*Alamat penulis korespondensi: Departemen Proteksi Tanaman, Fakultas Pertanian, Institut Pertanian Bogor, Kampus Darmaga, Jalan Kamper, Bogor 16680

Tel: 0251-8629364, Faks:0251-8629362, Surel: gedesuast@yahoo.com 


\section{PENDAHULUAN}

Bawang merah (Allium cepa) merupakan salah satu komoditas hortikultura yang banyak dikonsumsi penduduk Indonesia dan mempunyai nilai ekonomi cukup penting sehingga lalu lintas antardaerah komoditas ini cukup tinggi. Berdasarkan data BPS (2012) produksi bawang merah tahun 2010 mencapai 1048934 ton. Virus penting pada bawang merah antara lain Onion yellow dwarf virus (OYDV), Mite-borne filamentous virus (MbFV), Shallot latent virus (SLV), dan Shallot yellow stripe virus (SYSV) (Diekmann 1997; CABI 2007).

Budi daya bawang merah di Indonesia, khususnya di Kabupaten Bantul, dilakukan dengan penanaman umbi bibit. Hal ini memperbesar peluang tersebarnya virus. Oleh karena itu, penelitian ini bertujuan mendeteksi dan mengidentifikasi virus yang terbawa pada umbi bawang merah.

\section{BAHAN DAN METODE}

\section{Pengambilan Sampel Bawang Merah}

Bawang merah diambil secara acak dari 4 varietas (Jawa, Biru, Nganjuk, dan Brebes) dari Kabupaten Bantul, Yogyakarta. Sampel bawang merah diambil pada tiga titik (bagian depan, tengah, dan bagian belakang) di dalam gudang penyimpanan umbi bawang merah. Sampel ini dicampur sampai homogen sehingga didapatkan sampel komposit. Sebanyak $2 \mathrm{~kg}$ sampel kiriman diambil dari sampel komposit dan dipisahkan menjadi dua bagian, yaitu sampel arsip sebagai cadangan dan sampel kerja untuk pemeriksaan virus.

\section{Isolasi RNA dan Sintesis Complementary DNA}

Pemeriksaan virus dilakukan dengan mengambil 30 umbi bawang merah dari sampel kerja dan ditumbuhkan pada tanah steril di rumah kasa. Setelah tanaman berumur 20 hari, sampel daun diambil secara komposit yang masing-masing mewakili 5 tanaman untuk dideteksi dengan metode two-step RTPCR. Ekstraksi RNA total dilakukan dari $0.1 \mathrm{~g}$ daun bawang merah menggunakan Xprep Plant RNA Mini Kit (Philakorea Technology). Sintesis cDNA menggunakan First-Strand cDNA Synthesis Kit (GE Healthcare). Prosedur ekstraksi RNA total dan sintesis cDNA dilakukan sesuai protokol pada kit.

\section{Amplifikasi RT-PCR}

Reaksi PCR dilakukan dengan menggunakan MasterMix (Qiagen) serta primer spesifik untuk deteksi protein selubung OYDV, SYSV, SLV, dan ShVX (Tabel 1). PCR dilakukan pada mesin veriti-applied biosystem dengan kondisi reaksi denaturasi awal pada suhu $95^{\circ} \mathrm{C}$ selama 5 menit, sebanyak 35 siklus pada suhu denaturasi $95^{\circ} \mathrm{C}$ selama 1 menit; penempelan primer (OYDV dan SYSV pada suhu $57^{\circ} \mathrm{C}$ selama 45 detik; SLV $55.8^{\circ} \mathrm{C}$ selama 45 detik; ShVX $55^{\circ} \mathrm{C}$ selama 1 menit). Ekstensi (OYDV, SYSV dan SLV) pada suhu $72{ }^{\circ} \mathrm{C}$ selama 1 menit, sedangkan untuk ShVX pada suhu $72^{\circ} \mathrm{C}$ selama 1.5 menit. Selanjutnya tahap ekstensi akhir pada suhu

Tabel 1 Primer yang digunakan untuk reaksi amplifikasi PCR

\begin{tabular}{|c|c|c|c|}
\hline $\begin{array}{l}\text { Virus } \\
\text { target }\end{array}$ & Primer & $\begin{array}{l}\text { Produk PCR } \\
\quad(\mathrm{pb})\end{array}$ & Sumber \\
\hline OYDV & $\begin{array}{l}\text { F 5'- CGAAGCAAATTGCCAAGCAG -3' } \\
\text { R 5'- CGATTAGCTGCCCCTCTAAC -3' }\end{array}$ & 601 & $\begin{array}{l}\text { Mahmoud et al. } \\
\text { (2007) }\end{array}$ \\
\hline SYSV & $\begin{array}{l}\text { F 5'- ACACGAGCCACACACGCACA -3' } \\
\text { R 5'- TCCCTAACAAAACGTGCAACACTCA -3, }\end{array}$ & 749 & NCBI (2011) \\
\hline SLV & $\begin{array}{l}\text { F 5'- AAACCTTTTGGTTCACTTTAGG -3' } \\
\text { R 5'- GCGTGCTATATTTAAGTTGCATAC -3' }\end{array}$ & 992 & $\begin{array}{l}\text { Torrico et al. } \\
\text { (2010) }\end{array}$ \\
\hline ShVX & $\begin{array}{l}\text { F 5'-ATTTAGGGGTGAAGGTCTGT -3' } \\
\text { R 5'- GAGTTTTGAGGTCGTTGG -3' }\end{array}$ & 912 & $\begin{array}{l}\text { Egusquiza et al. } \\
\text { (2008) }\end{array}$ \\
\hline
\end{tabular}


$72{ }^{\circ} \mathrm{C}$ selama 7 menit. Hasil PCR dielektroforesis menggunakan Mupid-eXu pada tegangan 100 Volt selama 30 menit dan didokumentasikan menggunakan Gel Doc (Bio-Rad).

\section{Perunutan DNA dan Analisis Filogenetika}

Perunutan basa nukleotida dilakukan dengan mengirim sampel hasil PCR First Base Genetica Science (Singapura). Hasil runutan DNA disejajarkan (align) dengan data virus yang tersedia di GenBank menggunakan program basic local aligment search tool (BLAST) yang terdapat pada situs National Center for Biotechnology Information (NCBI) (www.ncbi.nlm.nih.gov). Selanjutnya analisis homologi dilakukan terhadap isolat virus lain yang tersedia pada GenBank menggunakan BioEdit versi 7.0.0 dan dilanjutkan pembuatan pohon filogenetika menggunakan program Mega v 4.0 untuk menunjukkan kekerabatan dengan virus isolat lain yang tersedia pada GenBank.

\section{Kejadian Penyakit dan Daya Tumbuh}

Kejadian penyakit ditentukan berdasarkan hasil deteksi RT-PCR terhadap sampel individu dari sampel komposit yang sebelumnya terdeteksi positif SYSV. Persentase daya tumbuh didapatkan dengan menghitung umbi yang tumbuh dari 30 umbi yang ditumbuhkan untuk deteksi dan identifikasi virus.

\section{HASIL}

\section{Deteksi Virus}

Deteksi virus dengan RT-PCR dari masingmasing 6 sampel komposit menunjukkan tidak terdeteksi OYDV, ShVX dan SLV dari semua sampel komposit bawang merah. Hanya SYSV yang berhasil teramplifikasi dengan pita DNA berukuran $\sim 749$ pb. SYSV terdeteksi positif pada 5 dari 6 sampel komposit bawang merah varietas Jawa dan pada 4 dari 6 sampel komposit varietas Brebes (Gambar 1). Selanjutnya, kejadian penyakit SYSV ditentukan dengan mendeteksi sampel komposit yang positif secara individu, yaitu 25 sampel individu varietas Jawa dan 20 sampel individu varietas Brebes.

\section{Perunutan Basa Nukleotida dan Analisis Filogenetika}

Perunutan basa nukleotida gen CP SYSV berhasil mendapatkan sikuen sepanjang 709 pb. Analisis nukleotida runutan DNA SYSV menggunakan BLAST menunjukkan bahwa isolat SYSV asal varietas Jawa dan Brebes memiliki homologi nukleotida tertinggi dengan

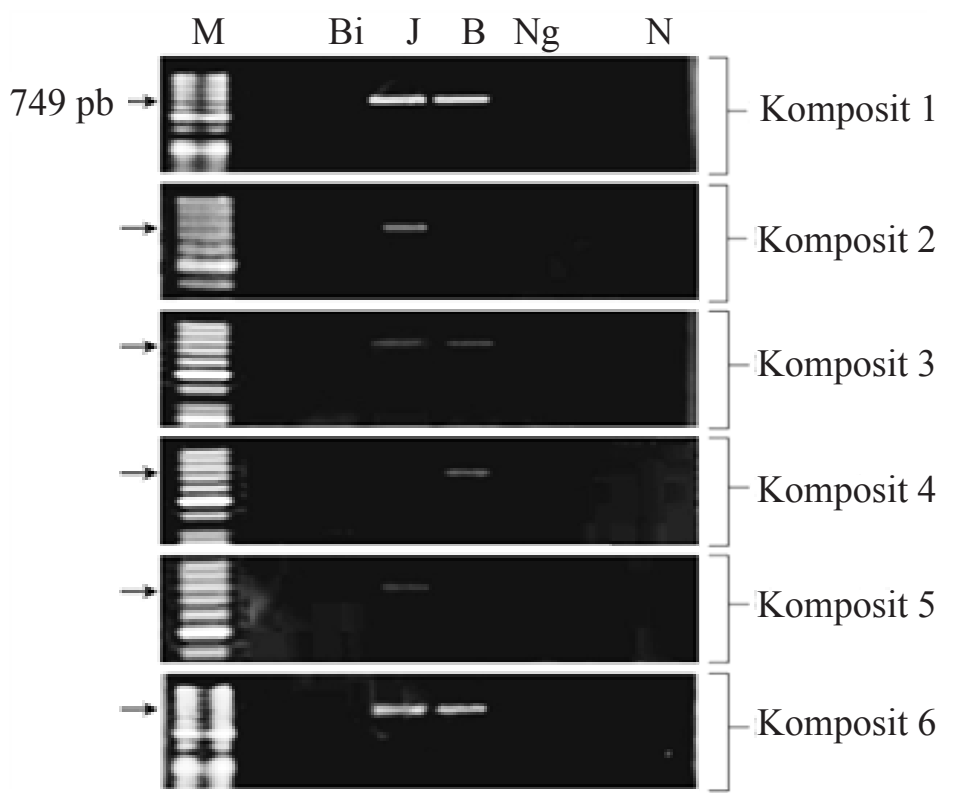

Gambar 1 Hasil PCR menggunakan primer spesifik SYSV terhadap komposit (1-6) sampel bibit bawang merah. Varietas bawang merah terdiri atas Bi, Biru; J, Jawa; B, Brebes; Ng, Nganjuk; M, 50 pb DNA Ladder (Thermo); N, kontrol negatif. 
SYSV isolat dari Cina, Jepang, Korea Selatan, serta Vietnam. Homologi nukleotida SYSV antara keduanya sebesar $100 \%$, sedangkan homologi kedua isolat terhadap SYSV isolat lain (isolat SYSV dari Cina, Jepang, Korea Selatan, serta Vietnam) berkisar 91.8-94.9\% dan $72 \%$ terhadap OYDV (Tabel 2).

Analisis filogenetika memperlihatkan dengan jelas bahwa isolat SYSV isolat Jawa dan Brebes berada pada kelompok yang sama dengan SYSV dari Cina, Korea Selatan, Jepang, dan Vietnam namun berbeda kelompok dengan OYDV sebagai outgroup dari genus yang sama, yaitu genus Potyvirus. Sebagai outgroup genus digunakan SLV (genus Carlavirus) yang juga dapat menginfeksi bawang merah (Gambar 2).

\section{Kejadian Penyakit dan Daya Tumbuh}

Pada 5 sampel komposit pada varietas Jawa dan 4 sampel komposit pada varietas
Brebes positif terdeteksi SYSV (Gambar 1), hasil deteksi sampel individu menunjukkan kejadian penyakit SYSV sebesar $60 \%$ pada varietas Jawa dan 53.3\% pada varietas Brebes (Gambar 3).

Apabila persentase infeksi SYSV pada bawang merah tersebut disandingkan dengan persentase daya tumbuh umbi, terlihat bahwa dengan adanya infeksi SYSV, daya tumbuh umbi varietas Jawa sebesar $83.3 \%$ dan varietas Brebes 73.3\% (Gambar 4).

\section{PEMBAHASAN}

Berdasarkan data GenBank SYSV isolat Jawa dan Brebes menunjukkan tingkat homologi yang tinggi (91-94\%) dengan isolat SYSV dari Cina, Jepang, Korea Selatan, dan Vietnam. Berdasarkan analisis homologi terhadap sikuen nukleotida protein selubung menunjukkan bahwa virus yang terdeteksi

Tabel 2 Homologi sikuen nukleotida protein selubung isolat SYSV pada bawang merah varietas Jawa dan Brebes dengan isolat virus pada bawang dari negara lain

\begin{tabular}{|c|c|c|c|c|c|c|c|c|}
\hline Nomor isolat virus & 1 & 2 & 3 & 4 & 5 & 6 & 7 & 8 \\
\hline 1 SYSV Jawa & - & 100.0 & 94.9 & 93.9 & 94.9 & 91.8 & 72.0 & 37.1 \\
\hline 2 SYSV Brebes & & - & 94.9 & 93.9 & 94.9 & 91.8 & 72.0 & 37.1 \\
\hline 3 SYSV Hangzhou Cina ${ }^{1 *^{*}}$ & & & - & 93.8 & 96.5 & 91.7 & 72.3 & 36.4 \\
\hline 4 SYSV wels onion Jepang ${ }^{2)^{*}}$ & & & & - & 93.5 & 92.5 & 71.2 & 36.4 \\
\hline 5 SYSV SSan Korea Selatan ${ }^{3)^{* *}}$ & & & & & - & 92.2 & 72.0 & 36.6 \\
\hline 6 SYSV VN/S1 Hue Vietnam ${ }^{4)^{*}}$ & & & & & & - & 71.1 & 36.8 \\
\hline 7 OYDV YH1 Zhejiang Cina $)^{5 *}$ & & & & & & & - & 35.4 \\
\hline 8 SLV WA-1 Australia ${ }^{6 * *}$ & & & & & & & & - \\
\hline
\end{tabular}

Kode aksesi pada GenBank: ${ }^{1)} \mathrm{AJ} 311370,{ }^{2)} \mathrm{AB} 353120,{ }^{3)} \mathrm{AB} 669435,{ }^{4} \mathrm{DQ} 925456,{ }^{5} \mathrm{AJ} 292231,{ }^{6} \mathrm{JF} 320811$, *dipublikasikan pada jurnal; ${ }^{* *}$ tidak dipublikasikan pada jurnal

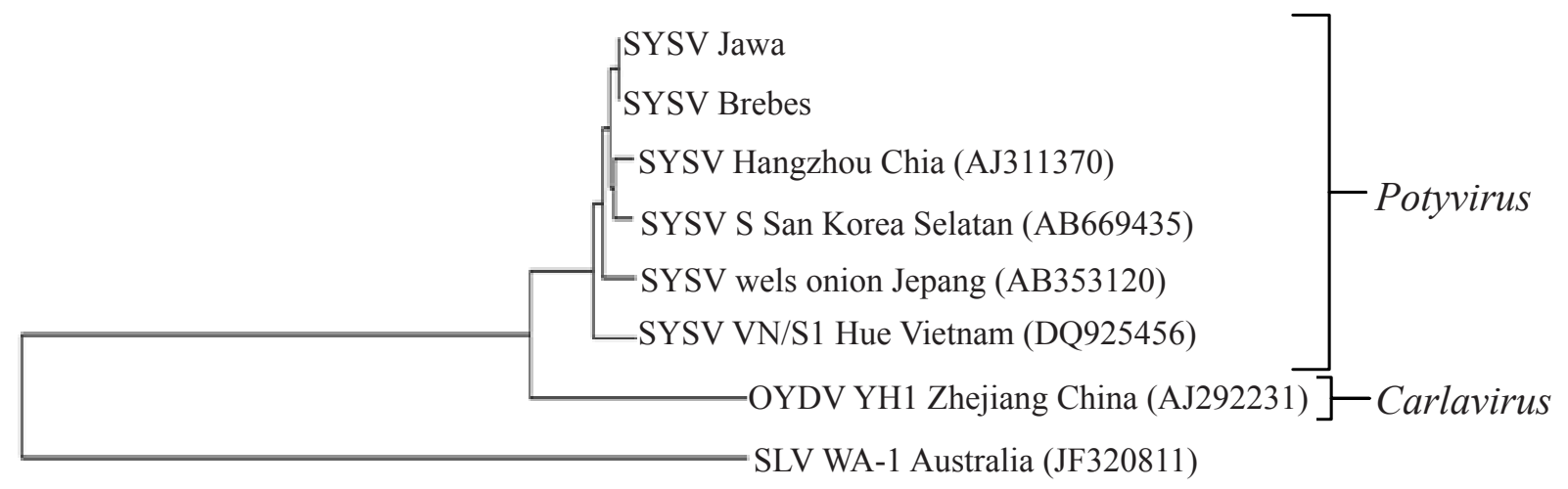

Gambar 2 Hubungan kekerabatan SYSV asal umbi bawang merah varietas Jawa dan Brebes dari daerah Bantul, Yogyakarta dengan SYSV negara lainnya. 

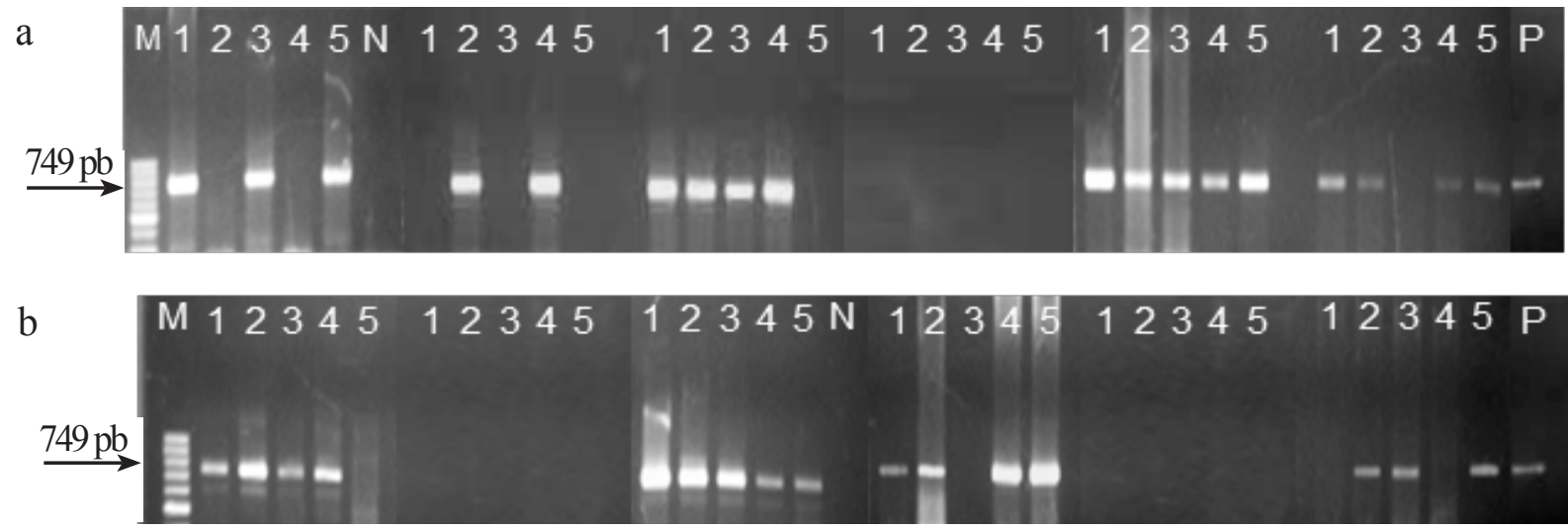

Gambar 3 Hasil amplifikasi SYSV pada setiap individu (1-5) dari 30 umbi bawang merah yang diuji. a, varietas Jawa; b, varietas Brebes; M, 50 pb DNA Ladder (Thermo); P, kontrol positif; dan N, kontrol negatif.

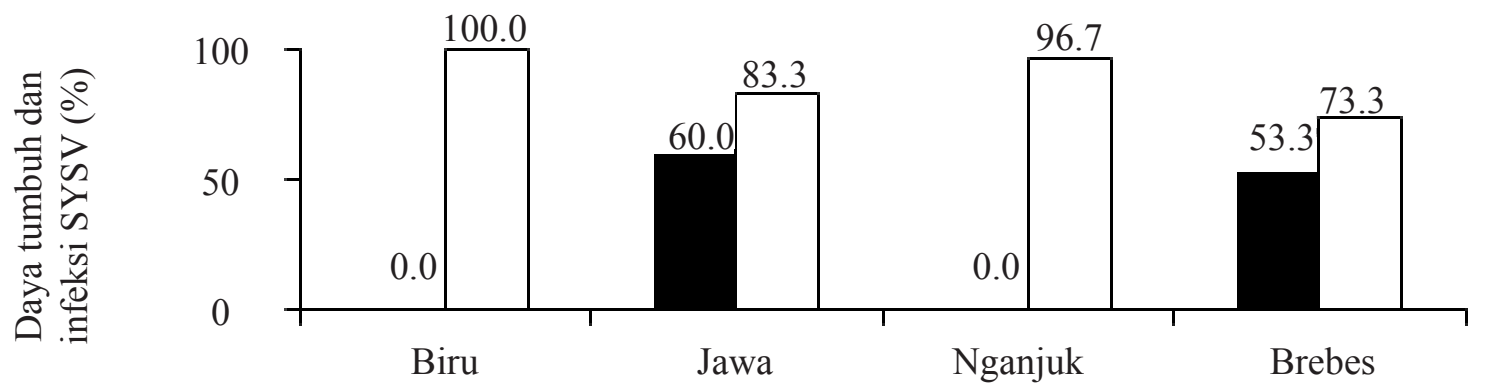

Asal sampel bawang merah

Gambar $4 \square$, daya tumbuh dan; $\boldsymbol{a}$, persentase infeksi SYSV pada 4 varietas sampel bibit bawang merah lokal.

pada varietas Jawa dan Brebes merupakan SYSV dan merupakan satu spesies yang sama dengan SYSV isolat lain (isolat SYSV dari Cina, Jepang, Korea Selatan, dan Vietnam) karena untuk genus Potyvirus, nilai homologi nukleotida virus 90-99\% dikategorikan sebagai satu spesies yang sama (Shukla dan Ward 1988). Hal ini didukung oleh kenyataan bahwa nilai homologi sikuen nukleotida SYSV isolat Jawa dan Brebes kurang dari 90\% bila dibandingkan dengan spesies lain (misalnya OYDV) di dalam genus Potyvirus. Dengan demikian berdasarkan hasil runutan DNA dan homologinya dengan isolat lain dapat dipastikan bahwa SYSV isolat Jawa dan Brebes adalah SYSV. Hal ini menambah informasi hasil penelitian Arisuryanti et al. (2009) yang menyatakan bahwa bawang merah di Yogyakarta dan Brebes terdeteksi beberapa macam virus antara lain OYDV, SLVdan Leek yellow stripe virus (LYSV).
SYSV isolat Jawa dan Brebes paling dekat kekerabatannya dengan SYSV isolatHangzhou Cina dan Korea Selatan. Berdasarkan Van der Vlugt et al. (1999) daerah sebar SYSV di antaranya ialah Cina dan Indonesia. Hal ini menunjukkan adanya kemungkinan bahwa SYSV isolat Hangzhou Cina, isolat Jawa, dan Brebes berasal dari sumber yang sama atau penyebaran SYSV ketiga isolattersebutmeliputi Indonesia (Jawa) dan Cina (Hangzhou).

Kejadian penyakit pada varietas Jawa dan Brebes berturut-turut $60 \%$ dan $53.3 \%$ lebih rendah daripada penelitian Gunaeni et al. (2011). Mereka menyatakan bahwa sebanyak 20 sampel bawang merah yang diambil dari Jawa Barat dan Jawa Tengah terdeteksi SYSV 95\%.

Pengaruh infeksi SYSV terhadap persentase daya tumbuh umbi relatif kecil, sedangkan umbi yang tidak terdeteksi adanya virus daya tumbuhnya jauh lebih baik. Diekmann (1997) menyatakan bahwa umbi 
bawang yang terserang masih mempunyai daya tumbuh baik dan masih dapat berproduksi. Arti penting secara ekonomi belum dilaporkan. Hal ini mengakibatkan tingginya potensi penyebaran SYSV melalui umbi sebagai bahan perbanyakan karena lalulintasnya menjadi terabaikan sehingga dapat mengancam produksi bawang merah jika pada suatu saat keberadaan virus ini menjadi dianggap penting di Indonesia, atau berpotensi menghambat ekspor bawang merah Indonesia jika pada suatu saat virus ini menjadi perhatian di dalam sanitary and phytosanitary measures dalam World Trade Organization (WTO).

\section{DAFTAR PUSTAKA}

Arisuryanti T, Daryono BS, Hartono S. 2009. Pengembangan metode skrining ketahanan tanaman bawang merah (Allium ascalonicum L.) terhadap virus menggunakan RT-PCR. Laporan Akhir Hasil Penelitian Hibah Bersaing (Tahun Kedua) Universitas Gadjah Mada Tahun Anggaran 2009. Yogyakarta (ID): Universitas Gadjah Mada.

[BPS] Badan Pusat Statistik. 2012. Luas Panen, Produksi dan Produktivitas Bawang Merah, 2009-2010. Jakarta (ID): Badan Pusat Statistik.

[CABI] Centre for Agricultural Bioscience International. 2007. Crop Protection Compendium [CD-Rom]. Wallingford (UK): CABI. 2 CD-Rom dengan penuntun di dalamnya.

Diekmann M. 1997. FAO/IPGRI Technical Guidelines for the Safe Movement of Germplasm Number 18 Allium spp. Roma (IT): FAO.

Egusquiza ZP, Ward LI, Clover GRG, Fletcher JD, Vlugt RAAVD. 2008. First report of Shallot virus $X$ in shallot in New Zealand [abstrak]. New Disease Reports. http:// www.ndrs.org.uk/article.php?id=018029 [diakses 18 Nov 2008].

Gunaeni N, Wulandari AW, Duriat AS, Muharam A. 2011. Insiden penyakit virus tular umbi pada tiga belas varietas bawang merah asal Jawa Barat dan Jawa Tengah. J Hort. 21(2):164-172.

Mahmoud SYM, Maaty SAAE, Borollosy AME, Ghaffar MHA. 2007. Identification of Onion yellow dwarf virus as one of the major viruses infecting garlic in Egypt. American-Eurasian J Agric Environ Sci. 2(6):746-755. DOI: http://dx.doi.org/ 10.3923/ijv.2008.1.13.

[NCBI] National Center for Biotechnology Information. 2011. Primer-BLAST: Finding primers specific to your PCR template using Primer3 and BLAST. http:// www.ncbi.nlm.nih.gov/tools/primer-blast [diakses 13 Jul 2011].

Shukla DD, Ward CW. 1988. Amino acid sequence homology of coat proteins as a basis for identification and classification of the Potyvirus group. J Gen Virol. 69:27032710. DOI: http://dx.doi.org/10.1099/00221317-69-11-2703.

Torrico AK, Cafrune EE, Conci VC. 2010. First report of Shallot latent virus on garlic in Argentina. Plant Dis. 97(7):915. DOI: http://dx.doi.org/10.1094/PDIS-947-0915B.

Van der Vlugt RAA, Steffens P, Cuperus C, Barg E, Lesemann DE, Bos L, Vetten HJ. 1999. Further evidence that Shallot yellow stripe virus (SYSV) is a distinct Potyvirus and reidentification of Welsh Onion yellow stripe virus as a SYSV strain. Phytopathology. 89(2):148-155. DOI: http://dx.doi.org/10.1094/PHYTO. 1999.89.2.148. 